\title{
Research on the Reform of the Basic Curriculum of Electrical and Electrical Courses in Colleges and Universities
}

\author{
Haiyan Wang \\ Changchun University of science and technology, Changchun 130000, China \\ 13742883@qq.com
}

Keywords: Teaching Reform; Basic Electrical Classes; The Practice Teaching; According to the Column of Teaching.

\begin{abstract}
With the growing demand for applied talents for society, institutions of higher learning to deal with the traditional teaching mode reform, training to adapt to the new situation and new situation of professional talents, set up to meet the needs of the social personnel training mode. Electricity class specialized basic course is the professional information disciplines important professional foundation course, the teaching idea, teaching method, teaching mode has a lot of problems, in accordance with the standards of training applied talents for the electricity class foundation course reform innovation is of great significance.
\end{abstract}

\section{Introduction}

Along with the social demand for applied talents increases increasingly, institutions of higher learning to deal with the traditional teaching mode reform, training to adapt to the new situation and new situation of professional talents, set up to meet the needs of the social personnel training mode.

Electricity class specialized foundation contains "circuit basis", "analog electronic technology" and "digital electronic technology" course, is the professional information disciplines important professional foundation course. Such courses contain a large number of laws, theorems, arguments, reasoning and conclusions. Students are trained by understanding and mastering the basic skills of scientific research. Broad application background of the curriculum, various curriculum connection is complex, practical application case is more, students should apply the theoretical knowledge into practical application, enhance its ability to find and solve problems. So electricity class specialized basic course teaching is a solid foundation to learn other professional course, the according to cultivate applied talents training mode reform is urgent and necessary, is of great significance.

\section{Current problems in the teaching of electric courses in colleges and universities}

\subsection{Heavy digital circuit, light analog circuit.}

In recent years due to the popularity of digital electronics, analogue electronic increasingly ignored: without a doubt, traditionally belong to a lot of features in the field of analogue electronics, today can be implemented in digital form. Such as digital audio, the analogue signals generated by the microphones and other sound sensor using some reasonable amplifier and filter processing, converted to digital form for further processing, such as mixing, edit, and produce some special effects. Finally, the digital signal is converted back to the analogue signal and played through the speaker. One of the main reasons for wanting to do as many functions as possible in a digital way is due to the high reliability and high flexibility of digital circuits. 


\subsection{Reintegrated circuit IC, discrete components.}

Today's IC technology is changing, both in analogue circuits and in digital circuits. In computers, for example, almost all circuits are IC except for the power circuit, and it is difficult to find discrete components such as transistors and FET. With the development of IC element IC, circuit design is more convenient. This leads to the tendency of students to use IC circuits in their learning and experimentation, but this also leads to the inability of students to properly handle glitches in the circuit.

\subsection{Software simulation, light hand practice.}

Computer simulation design has become an important content of training students' engineering practice ability, but it has already existed in the teaching. Through a variety of simulation software to design a practical circuit and system, but the results of simulation and actual circuit is different, the simulation verified the feasibility of the circuit and the system only in theory, but used in practice to consider many factors, such as work environment, the product cost, etc., so the idea of soft light hard is wrong.

\subsection{Misuse of multimedia.}

The use of multimedia is informative and informative. But the course that contains a large number of equations and important formulas in lectures does not apply. Due to the need when using slides teaching often turn pages, caused the student thought not continuity, class effect is not very good, student's energy easily attracted by the style of the multimedia courseware, lead to a class effect is not very ideal.

\section{Concrete reform measures to address practical problems}

\subsection{Teaching method reform}

The traditional teaching method is the teacher cantered, the student is in the state of being beaten, the teaching method of "cramming" is very common. After the teacher has finished the class, lack of communication with the student, cannot understand the student's understanding of knowledge and grasp the situation in time. In class, teaching is usually first about concepts, theories, methods, and then examples, and rarely interact with students. The whole teaching process embodies mainly on teachers, students just passively accept knowledge, the enthusiasm of the students' initiative thinking and active learning is not mobilizing, learned knowledge cannot good to solve practical problems.

According to the national policy, many universities are facing transformation, and the training target is also aimed at cultivating the applied type talents. It is urgent to take advantage of the experience of similar courses in China and abroad to learn from the experience of building the electric field. Teaching with discussion in the teaching process should be adopted, in order to arouse the enthusiasm of students' active learning, each class can define a central issue, you learn while discussion, introducing more actual case, to improve students' ability to solve practical problems and the ability to practice and practice. Experiment teaching reform at the same time, the theory of professor, the unit for discussion and practice three complement each other, extension and supplement each other, in order to gain good teaching effect.

\subsection{Teaching content reform}

\subsubsection{The teaching content is distinct}

In the course of teaching, the teacher should give the overall framework to the content system of each course, and make clear the connection between the parts. Divide the course of each course from difficulty, height and degree of guidance; Targeted students are taught to understand the key points, difficulties and hot spots so that students can study and improve themselves after class. 


\subsubsection{Each section of the course adds a certain amount of self-taught content}

Teaching students is the main body of teaching, teachers should abandon "cramming" teaching, adopt heuristic method, reduce the teaching time, increase the time and the content of students' autonomous learning, for each chapter of the course content could add just the right amount of selfstudy, to carry out academic report or submit the form of a small paper, improve the students' selfstudy part consciousness and innovative, improve the ability of solving practical problems.

\subsubsection{Introduction of example teaching}

Electricity class specialized basic course teaching content contains a lot of original and practical application circuit, if only in accordance with the teaching reference books on the theory of knowledge teaching, students are not easy to remember; In the appropriate introduction of case teaching in the teaching process, and can change the traditional "cramming" teaching mode, to enable students to zero distance contact the actual components, circuits and systems, improve the students' ability in time, widened the field of vision, improve the learning interest. Real case teaching is a necessary link in the process of classroom teaching, teachers guided by professor instead, students from passive learning into active study, the effect of the improvement of theoretical teaching and improve the play a very important role.

\section{Conclusion}

In a word, the traditional electric kind of basic course teaching material and teaching too much emphasis on knowledge system of deduction and reasoning, students in the learning process is difficult to understand and digest, directly affected their learning enthusiasm, initiative. It is difficult to learn the following specialized courses, and also influence the professional education, which affects the students' employability. Therefore, to solve the practical problem is to reform the basic teaching of electrical class. Make such courses "to see and touch to see", lets the student in the classroom to see the effect of practical application, is to improve the students' learning interest and initiative of the effective teaching method, is also the important way to improve students' ability to solve practical problems.

\section{Acknowledgments}

The 13th five-year plan of the education science in jilin province is planned for 2017. 《The study of the basic course teaching mode of the innovative talents training target $》$.Project approval number GH170977

\section{References}

[1]. Wang Changshun wei-gang pan. Applied talents training mode reform of electricity class specialized practice teaching [J]. Science and technology innovation herald, 2017. (01): $186+188$.

[2]. in the valley of love yu, zhang, yi-min xia, xie. Electricity class foundation course teaching reform practice [J]. Journal of electrical and electronics teaching, 2017, (01): 37 + 36-142.

[3]. The university of shaanxi normal university, shaanxi normal university, 2016.

[4]. zhao xiaofeng. The study of the method of vocational training for students of electrical automation in higher vocational colleges [D]. Chengdu sports institute, 2015.

[5]. Zhang Zhimei Cheng Liying, JiWeiYi. Basic course teaching reform of electronic and information profession explore [J]. Journal of shenyang normal university (natural science edition), 2013, (4): 552-555.

[6]. zhang qi-ye.based on the theory of high vocational high vocational high vocational college, [D].huazhong normal university, 2011. 
[7]. Wang yongfang. Reform and practice of advanced mathematics courses in high vocational and mechanical majors [D]. University of suzhou, 2007. 